\author{
С.Ф. Легенчук, д.е.н., проф. \\ В.Р. Очередько, магістрант \\ Державний університет «Житомирська політехніка» \\ І.В. Орлов, д.е.н., проф. \\ Н.С. Стойка, к.е.н., доц. \\ Закарпатський угорський інститут імені Ференияа Ракоиі II
}

\title{
Нематеріальні активи в системі управління логістичними компаніями: облікові перспективи
}

Розкрито важливість впровадження інформаційно-комунікаційних технологій у логістичних компаніях. Розглянуто найбільш поширені нематеріальні активи в різного типу логістичних компаніях залежно від ступеня інтегрованості їх діяльності з бізнесом замовника та кількості виконуваних логістичних функцій. Встановлено, щзо нематеріальні активи у вигляді інтелектуального капіталу - ие знання та вміння персоналу, бази даних, програмне забезпечення, патенти, торгові марки тощо, $\epsilon$ найбільш поширеними в постачальників логістичних послуг видами ресурсів, які не мають матеріальної форми.

Встановлено необхідність здійснення досліджень $і$ розробок або науково-дослідних та дослідно-конструкторських робіт (НДДКР) логістичними компаніями та їх вплив на конкурентні переваги фірми. Визначено основні тенденції, пов'язані з використанням нематеріальних активів, щзо вплинуть на розвиток логістики та ланцюгів поставок у найближчому майбутньому.

Проаналізовано результат впровадження інноващій, щзо безпосередньо пов'язаний 3 ефективністю діяльності підприємства. Обтрунтовано роль нематеріальних ресурсів у формуванні конкурентних переваг логістичних систем. Визначено перспективи розвитку обліку в контексті використання нематеріальних активів логістичними компаніями.

Ключові слова: нематеріальні активи; НДДКР; конкурентні переваги; постачальники логістичних послуг.

Актуальність теми. Сучасна економіка характеризується ринковим середовищем, що швидко змінюється, скороченням життєвого циклу продуктів і послуг, глобалізацією господарських зв'язків на базі інтернету і сучасних інформаційно-комунікаційних технологій, кліентоорієнтованістю і постійним пошуком нових можливостей для розвитку бізнесу. Завдяки наукомісткому виробництву, 3D-друку, інтернету речей, хмарним технологіям, базам знань докорінній трансформації підлягають соціальноекономічні відносини. Шляхом якісних нововведень у різних секторах економіки, у тому числі і в логістиці, створюється потужний поштовх, який сприяє зростанню продуктивності і призводять до появи нових продуктів.

Вагомо на різні сегменти ринку логістичних послуг і на інтегративні процеси в ланцюгах поставок впливають зміни, пов'язані з розвитком інтернету та електронного бізнесу. За свідченнями експертів ITіндустрії, до 2025 року нові інформаційно-комунікаційні технології разом з використанням великих обсягів даних і можливістю їх оброблення в режимі реального часу зроблять пересування товарів і людей більш дешевими, швидкими і безпечними.

Підтвердженням цього є наукова програма Європейського Союзу «Horizon-2020», яка передбачає значне фінансування розробки глобальних IT-технологій в сфері логістики, що в майбутньому може стати єдиним віртуальним простором для формування логістичних мереж і появи нових бізнес-моделей діяльності постачальників логістичних послуг [2, с. 36].

Однак існуюча на сьогодні ситуація потребує втручання вчених для іï покращання, оскільки менеджмент значної кількості логістичних підприємств звертає свою увагу лише переважно на те, яким чином слід мінімізувати свої логістичні витрати шляхом впровадження режимів економії витрат на заробітну плату персоналу та доставку товарів (робіт, послуг) їх замовнику. При цьому майже не приділяється увага стратегічному інноваційному розвитку логістичних підприємств.

Як зауважують дослідники, сучасні постачальники логістичних послуг недооцінюють значущість інновацій і тільки 0,1 \% річного доходу вкладають у дослідження і розробки. Лише 20 \% компаній, що працюють в транспортному секторі, є інноваційними $[2,7,9]$. Наведене вище $є$ свідченням того, що питанням обгрунтування важливості і ролі нематеріальних активів компаній, процесам їх створення та збереження їх вартості варто приділяти більшу увагу, адже саме вони є результатом інноваційної діяльності.

(C) С.Ф. Легенчук, В.Р. Очередько, І.В. Орлов, Н.С. Стойка, 2020 
Аналіз останніх досліджень та публікації, на які спирається автор. На сьогодні велика кількість досліджень присвячена виявленню впливу нематеріальних активів та специфічних видів нематеріальних активів (таких як патенти, торгові марки, НДДКР тощо) на діяльність фірми, їі вартість, рівень продуктивності, економічне зростання тощо. Особлива увага вченими приділяється взаємозв'язку між структурою управління підприємства та нематеріальними активами, зокрема інвестиціям у дослідження і розробки. Питанням визначення ролі та місця нематеріальних ресурсів у діяльності компанії в цілому, а також впливу такого роду активів на конкурентні переваги фірми були присвячені роботи багатьох українських та зарубіжних вчених, таких як: М.Анхольцер, О.В. Безсмертна, М.Ю. Григорак, Є.С. Денисевич, І.Ф. Слфімова, Д.Є. Зайцева, М.Ігельський, А.Кава, Д.Крессвелл, В.В. Кривещенко, Б.Пітерс, О.В. Позняк, та ін. Зокрема у своєму дослідженні М.Очак та Д.Фіндик [12, с. 2] показують, що наразі фірми інвестують більше у нематеріальні активи, ніж у матеріальні, оскільки перші відіграють ефективну роль у підтримці конкурентоспроможності фірми та ії інтерналізації. Нематеріальні активи, такі як програмне забезпечення та НДДКР, є критично важливими інвестиціями, які забезпечують та підтримують присутність фірми на ринку в майбутні роки за рахунок зменшення витрат та збільшення прибутку. Тобто їх можна вважати стратегічними інвестиціями для довгострокового шляху зростання компанії. Феррейра К. [8, с. 7] також зазначає, що найбільш значний внесок у продуктивність фірми роблять програмне забезпечення та витрати на дослідження і розробки, підкреслюючи вирішальну роль інноваційного капіталу в цьому секторі.

Метою статті $є$ визначення ролі нематеріальних активів у діяльності логістичних компаній, а також їх впливу на конкурентні переваги постачальників логістичних послуг.

Викладення основного матеріалу. Галузь логістичних послуг можна вважати «стимулятором» економічного розвитку, що підтверджується сильною кореляцією між станом економіки і попитом на логістичні послуги. Логістичні компанії є важливими партнерами сучасних організаційних структур. Без їхніх послуг багатьом суб'єктам господарювання було б важко вийти на нові ринки або навіть поставляти продукцію клієнтам, що знаходяться в різних регіонах однієї країни. Особливо це помітно в сфері електронної комерції, динамічний розвиток якої є однією 3 найважливіших тенденцій сучасної економіки. Без послуг експрес-доставки, шафок для зберігання посилок та пунктів їх прийому і видачі, інтернет-продажі були б практично неможливі.

На сьогодні в світовій практиці для обгрунтування видів логістичної діяльності використовується спеціальна розроблена типізація - 1PL, 2PL, 3PL, 4PL, 5PL, виходячи з якої обгрунтовується унікальність кожного типу, визначаються відмінності між ними та особливості функціонування логістичних компаній, які належать до кожного з таких типів. Проаналізувавши наведені вище типи, можна визначити зміни, які в останні роки відбулися в сфері логістичної діяльності, що є наслідками активного використання інтернет-технологій для комунікації між споживачами та постачальниками товарів, робіт і послуг, обов'язкового впровадження логістичних комп'ютерних інформаційних систем, інших забезпечуючих інформаційних систем, створення спеціалізованих вебсервісів, інформаційних порталів, платформ, застосування нових програмних засобів (інтелектуальний аналіз, Big Data, Інтернет речей, хмарні обчислення, блокчейн тощо). В цілому такі технологічні інновації спрямовуються на мінімізацію логістичних витрат підприємств та підвищення якості послуг, що в кінцевому підсумку має завершитися формуванням сучасної комплексної логістичної системи, яка забезпечуватиме інтеграцію інформаційних, інтелектуальних та навігаційних технологій.

Розглядаючи окремі типи постачальників логістичних послуг, можна виокремити особливості використання в них нематеріальних активів. Зокрема, комплексні (3PL) і логістичні (LLP) провайдери, а також системні інтегратори (4PL) більше приділяють увагу координації потокових процесів між різними ланками ланцюга поставок, тому пріоритетними для них $є$ організаційні та ресурсні інновації для підвищення якості персоніфікованого обслуговування клієнтів. Вони більше орієнтуються на нематеріальні активи у вигляді інтелектуального капіталу - знання та вміння персоналу, бази даних, програмне забезпечення, патенти, торгові марки тощо.

Одним із найважливіших нематеріальних ресурсів сучасних підприємств є знання працівників. Ключовими компетенціями 4PL (системний інтегратор ланцюга поставок) є розробка комплексних рішень 3 управління ланцюгами поставок. Ці компанії можна вважати такими, що пропонують експертні знання для створення та управління складними логістичними системами, враховуючи логістичний консалтинг та організацію інформаційної інфраструктури, транспорту та логістики. Такі особливості вимагають від персоналу організаторських здібностей та специфічних знань [10, с. 33]. Окрім зазначених вище знань, логістичним компаніям необхідні кваліфіковані і досвідчені працівники, які співпрацюють 3 більш дрібними постачальниками логістичних послуг та іншими підрядниками.

Дослідники зазначають, що 3PL (комплексні логістичні оператори) характеризуються довгостроковими формальними або неформальними відносинами між конкретним підприємством і постачальником послуг з приводу покращення логістичної діяльності компанії частково або в цілому. Особлива увага тут приділяється довгостроковим відносинам з реципієнтами і постачальниками 
логістичних послуг. На думку вчених, співпраця досвідчених партнерів призводить до індивідуального підходу до кожного замовлення, більш широкого портфеля пропонованих послуг і тривалішого періоду часу співпраці, що більш вигідно для обох сторін відносин [10, с. 33].

Найбільші постачальники логістичних послуг - це добре відомі компанії, бренди яких цінуються по всьому світі. Імідж фірми пов'язаний з маркетингом і діловою ідентичністю. Вона відображає те, як організація сприймається клієнтами, постачальниками і конкурентами. Позитивні асоціації 3 фірмою вселяють довіру серед співробітників, підвищують почуття захищеності і знижують ризик провалу співпраці. Цей образ використовується при виборі партнерів у сфері логістичних послуг. Крім того, деякі вчені розглядають репутацію і корпоративний імідж як організаційні ресурси, які можуть позитивно впливати на стратегію і цілі логістичної компанії [10, с. 33-34].

У сучасних умовах ситуація 3 пандемією COVID-19 остаточно довела важливість стрімкого впровадження інформаційно-комунікаційних технологій в логістичних компаніях. Основні проблеми сьогодні торкаються логістики у зв'язку з карантинними обмеженнями, тривалими затримками поставок, невизначеністю термінів, пересуванням вантажів між кордонами, псуванням товару з певними строками зберігання тощо. Експерти 3 логістики вже багато років говорять своїм клієнтам в консалтингових логістичних проєктах i аудиті про необхідність оптимізації бізнес-процесів для їх подальшої автоматизації. Підкреслюють, що симбіоз логістики та інформаційних технологій (IT) в сьогоднішньому бізнесі дають величезну конкурентну перевагу. Тому впровадження IT-технологій можна вважати першим трендом у новій реальності. Застосування електронного документообігу від виробника до споживача, особливо на ринку В2В. Другим трендом в світі $є$ побудова нової логістики - інтернет логістики. Продовжать своє існування лише ті компанії, які зможуть дуже швидко перебудувати свою логістику під нові запити ринку [4, с. 181].

Для підтримки високого темпу зростання логістичні підприємства можуть удосконалювати старі та/або пропонувати нові послуги, модернізувати процеси, впроваджувати новітні ІТ-технології для скорочення витрат, боротися за незайняті ринки, впроваджувати нові моделі ведення бізнесу, акумулювати міжнародний досвід тощо. Базисом для формування конкурентних переваг логістичної системи є економічні ресурси логістики. Під цим поняттям варто розуміти сукупність матеріальних і нематеріальних факторів та засобів, що забезпечують безперебійність процесу планування, виконання та контролю руху економічних потоків в межах системи, створеної для досягнення своїх специфічних ідей [5, с. 255]. Щодо нематеріальних активів логістичної системи, то їх можна поділити на такі категорії:

- власні технології та стратегічні активи логістичних фірм;

- «гудвіл» (репутаційні активи);

- інформаційна інфраструктура.

Власні технології містять патенти, авторські права i виробничі секрети, які дозволяють використовувати унікальні знання з вигодою, зокрема організаційні та управлінські. Стратегічні активи можна охарактеризувати як наявні в організації переваги, завдяки яким їй вдається займати найвигіднішу конкурентну позицію, в тому числі монополістичну, або обслуговувати унікальний сегмент ринку. «Гудвіл» (репутаційні активи) - імідж, марки тощо, наявність яких сприяє зміцненню довіри клієнтів та споживачів логістичних послуг до їх виробника, що спостерігається у збільшенні обсягів продажів.

Особливо важливу роль у нематеріальних активах відіграє інформація (як трансформовані знання) i методи обгрунтування рішень, що використовуються при функціонуванні систем логістики (в управлінні запасами, транспортуванням, складським господарством, упаковкою, в організації інформаційного і фінансового супроводу матеріальних логістичних потоків. Масовість, необхідність оперативної обробки (у реальному масштабі часу), багаторазове використання інформації та ії носіїв у процесі управління - це ті категорії, які характеризують інформаційні потоки логістичних процесів. Таким чином створюються об’єктивні умови для застосування відповідних засобів і технологій обробки інформації, що також вважаються важливими компонентами інфраструктури логістичних процесів [5, с. 256].

Оскільки основою логістичної комунікації є робота із замовленнями клієнтів, то в такому випадку особлива увага приділяється швидкості і якості інформаційного потоку, адже саме ці фактори можуть істотно вплинути на витрати. ІТ-технології використовуються не тільки для прийому замовлень, але і в управлінні запасами готової продукції, у вимірі продуктивності, в процесі управління зберіганням i транспортуванням. Таким чином, логістичні інформаційні системи розглядаються як найважливіший елемент конкуренції. Кожна компанія прагне скоротити час циклу замовлення, підвищити швидкість реакції і знизити рівень запасів у логістичному ланцюжку, для чого можна використовувати логістичні технології, такі як система швидкого реагування, система «якраз вчасно» (just-in-time) або ефективна реакція на запити споживачів. Ці системи засновані на поєднанні різних інформаційних технологій. Керівництво компанії також використовує системи підтримки прийняття рішень, які являють собою спеціалізовані комп’ютерні системи, що дозволяють приймати більш ефективні рішення, або навіть різні експертні системи [11, с. 32-33]. 
У результаті досліджень неодноразово було виявлено, що впровадження інновацій впливає на ефективність діяльності підприємств через удосконалення процесу управління потоковими процесами та зниження загальних витрат на їх реалізацію. Однак й досі велика кількість організацій не усвідомлює, наскільки важливими для розвитку бізнесу є інновації та використовує застарілі методи здійснення логістичних операцій, в той час як інші шукають способи їх оптимізації.

Інноваційний проєкт, який фірма буде використовувати в своїй діяльності, може буде згенерований суб'єктом господарювання самостійно, або придбаний на стороні. Однак у будь-якому випадку процес створення такого проєкту є досить тривалим і потребує відповідних затрат. Дослідження і розробки або НДДКР є важливим аспектом діяльності компаній, логістичних зокрема, оскільки результатом таких дій $\epsilon$ забезпечення конкурентних переваг фірми. Це пов'язано з тим, що розвиток чекатиме лише на ті компанії, які будуть максимально швидко впроваджувати нові технології.

Сьогодні перед підприємствами постає завдання імплементувати в організаційну структуру філософію інноваційної логістики, тому що у майбутньому такий крок буде вирішальним у конкурентній боротьбі. Наприклад, організацією, яка активно використовує парадигму інноваційної логістики, є DHL. Вона $є$ світовим лідером у сфері логістики, визнаним експертом у галузях міжнародних експресвідправлень, повітряних, морських, автомобільних та залізничних перевезень, контрактної логістики i міжнародних поштових відправлень для своїх клієнтів. Компанія укомплектовує вантажівки за допомогою пристрою Smart Sensor. Така технологія дозволяє клієнтам компанії відстежувати температурні режими перевезення товарів та отримувати попереджувальний сигнал у разі їх порушення. Індикатор Smart Sensor надає замовникам контейнерів контроль за умовами перевезення продукції та гарантію якісної доставки [1, с. 562]. Таким чином, можна стверджувати, що реалізація інновацій в логістиці $є$ потужним інструментом в досягненні підприємством бажаних результатів з максимальною вигодою. Загальний процес виникнення і впровадження продуктів інноваційної діяльності компанії наведено в таблиці 1.

Таблиияя 1

Система інноваційної діяльності компанії [3, с. 25]

\begin{tabular}{|c|l|}
\hline Eman & \multicolumn{1}{|c|}{ Характеристика } \\
\hline \multirow{2}{*}{ Формування ідеї } & Формування задуму та інноваційної пропозиції \\
\cline { 2 - 2 } & Обгрунтування інноваційної пропозиції \\
\hline \multirow{2}{*}{ Розробка } & Стадії НДДКР \\
\cline { 2 - 2 } & Проєктування дослідних зразків \\
\cline { 2 - 2 } & Випробування споживчих якостей дослідних зразків \\
\hline \multirow{2}{*}{ Впровадження } & Обгрунтування інноваційних пропозицій \\
\cline { 2 - 2 } & $\begin{array}{l}\text { Стадія організації виробництва продукту (послуги) та підготовка до просування } \\
\text { на ринку }\end{array}$ \\
\hline \multirow{2}{*}{ Поширення } & Виробництво продукту, вихід на ринок або використання всередині фірми \\
\cline { 2 - 2 } & Використання продукту \\
\hline
\end{tabular}

Інноваційна складова дозволяє успішно прогнозувати інтенсивність та розмір матеріальних потоків, будувати гнучкі інтегровані системи управління рухом ТМЦ, а отже, оптимізувати кількість запасів сировини та готової продукції на складі, що призводить до підвищення ефективності управління обсягами продукції або послуг. Тому сьогодні моніторинг нововведень та розробка власних інноваційних проєктів мають бути в пріоритеті компаній, які прагнуть займати лідируючі позиції на ринку. Відштовхуючись від глобальних тенденцій розвитку світової економіки, існує цілий ряд досліджень, спрямованих на визначення головних світових трендів у різних сегментах та напрямах діяльності.

Так провідна 3PL-компанія Північної Америки «Cerasis» провела дослідження, завдяки якому визначила головні тенденції у сфері логістики та управління ланцюгами поставок [6, с. 151]. Значна частина існуючих трендів пов'язана саме 3 використанням нематеріальних активів у діяльності підприємства (табл. 2).

Таким чином, на сьогодні практично неможливо забезпечити необхідну споживачам якість обслуговування та ефективність логістичних операцій без застосування інформаційних систем i програмних комплексів для аналізу, планування та підтримки прийняття рішень 3 автоматизації типових операцій в транспортних і складських процесах. Поява нових мобільних і хмарних технологій, соціальних мереж і великих обсягів структурованих і неструктурованих даних обумовили зародження «нового стилю IT», який сприяє підвищенню гнучкості і швидкості обміну інформацією, формуванню колективного досвіду, оперативному виявленню проблем та прийняттю грамотних управлінських рішень [2, c. 35]. 
Тренди, по'вязані з використанням нематеріальних активів, щзо визначатимуть розвиток логістики та ланцюгів поставок у найближчому майбутньому за версією «Cerasis» [6, c. 152]

\begin{tabular}{|c|c|}
\hline Назва тренду & Пояснення \\
\hline $\begin{array}{c}\text { «цифрових } \\
\text { ланцюгів } \\
\text { поставок» }\end{array}$ & $\begin{array}{l}\text { Без цифрових технологій у ланцюгів поставок немає майбутнього. Відтак вимогою є } \\
\text { фокусування топменеджерів на створенні команд, спрямованих на виявлення } \\
\text { найкращих шляхів для використання потужного потенціалу цифрових технологій у } \\
\text { своїх ланцюгах поставок. Простежуватиметься тенденція до зростання інвестицій в } \\
\text { інновації. Так в нещодавньому опитуванні } 94 \% \text { виокремили «компетентність у } \\
\text { технологіях» як ключовий фактор під час розгляду процесів аутсорсингу ланцюгів } \\
\text { поставок, враховуючи використання постачальників логістики третьої сторони (3PL). } \\
\text { Поштовх до використання цифрових технологій також надає розвиток електронної } \\
\text { комерції, що, як очікується, буде зростати впродовж наступних семи років }\end{array}$ \\
\hline $\begin{array}{l}\text { Скорочення } \\
\text { часу доставки } \\
\text { замовлень } \\
\text { завдяки } \\
\text { візуалізації } \\
\text { даних }\end{array}$ & $\begin{array}{l}\text { Візуалізація даних - це технологія, яка може бути застосована до будь-якого } \\
\text { процесу постачання, який надає користувачам інформацію, що дозволяє негайно } \\
\text { коригувати операції або обмінюватися інформацією. Іншими словами, просту дію } \\
\text { формування звіту для керівника чи топ-менеджера можна вважати формою } \\
\text { візуалізації даних. Якщо звіт складено дуже добре, він може стати фундаментальним } \\
\text { поліпшенням ланцюга поставок }\end{array}$ \\
\hline $\begin{array}{l}\text { Зростання ролі } \\
\text { соціальних } \\
\text { медіа в } \\
\text { ланцюгах } \\
\text { поставок }\end{array}$ & $\begin{array}{l}\text { Ланцюги поставок активно використовують мобільні технології впродовж останніх } \\
\text { років. У найближчій перспективі їх значення лише зростатиме. Використання } \\
\text { облікових записів у соціальних медіа разом із маркетинговими інструментами } \\
\text { відіграватиме все більшу роль у підвищенні ефективності управління ланцюгами } \\
\text { поставок. Головний акцент тут - підтримка зв'язку зі споживачем }\end{array}$ \\
\hline
\end{tabular}

Розглянуті нематеріальні ресурси формують конкурентні переваги логістичної системи. В процесі логістичного обслуговування клієнтів їх застосування визначає важелі логістики - конкурентні можливості, що створюють основу для конкурентних компетенцій, які і визначають конкурентну перевагу, коли їі помічають споживачі логістичних послуг. Схематично цей взаємозв'язок показано на рисунку 1.

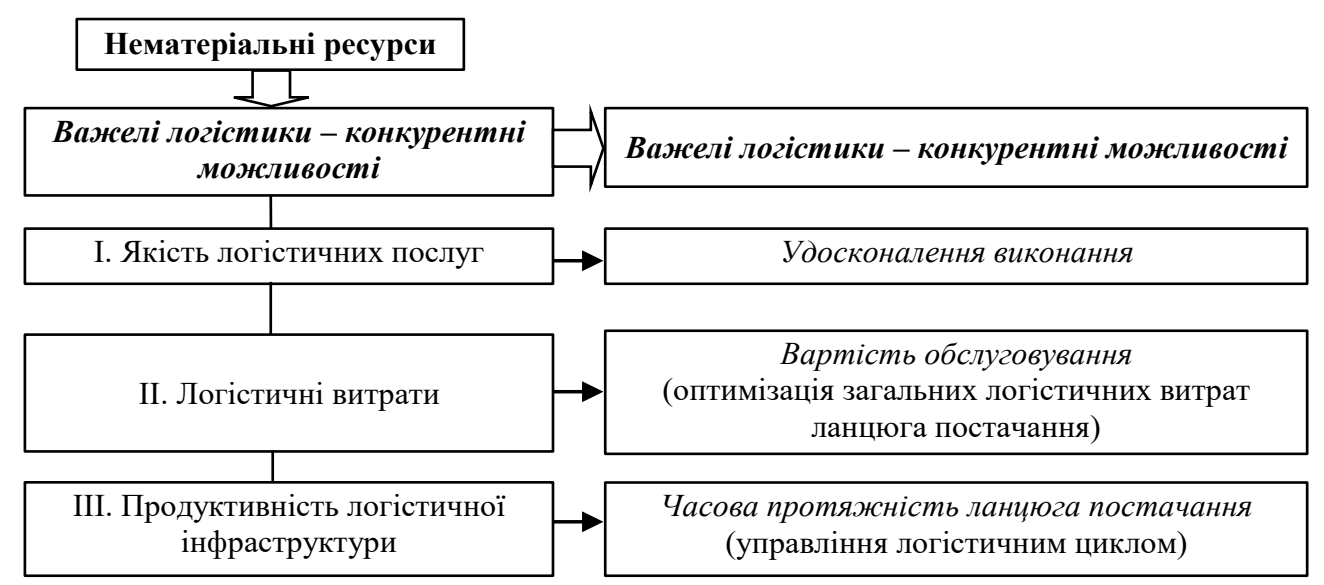

Рис. 1. Конкурентні переваги логістичних систем, забезпечені нематеріальними ресурсами [5, с. 259]

Задля того, аби компанія могла ефективно використовувати свої нематеріальні активи та займати лідируючі позиції на ринку логістичних послуг, такі ресурси мають достовірно відображатися в системі бухгалтерського обліку, яка є джерелом необхідно інформації для прийняття управлінських рішень. Саме тому варто звернути особливу увагу на особливості облікового відображення нематеріальних активів, а також виявити проблеми, що виникають під час цього процесу. Важливим аспектом цього питання $\epsilon$ визначення виду нематеріального активу, що розглядається, та особливостей нормативного законодавства в частині визнання та оцінки.

Висновки та перспективи подальших досліджень. Необхідність введення в дію сучасних та прогресивних технологій у сферу логістики набуває глобального характеру та пояснюється тим, що підприємства, які здатні найшвидше адаптуватися до ринкових умов і надати клієнтам продукцію відповідної якості, займатимуть провідні позиції у своїй галузі. Залежно від функцій логістичної компанії 
(1PL-5PL), зростає роль нематеріальних активів у їх діяльності. Зокрема, більшою мірою використовуються бази даних, програмне забезпечення, патенти, торгові марки, знання та вміння персоналу тощо. Також важливу роль у діяльності постачальників логістичних послуг відіграють НДДКР (дослідження і розробки), що $\epsilon$ складовою інноваційної діяльності підприємства. Доцільність застосування та імплементації інновацій в логістичні системи зумовлюється їх спроможністю впливати на створення нових форм комерційних операцій, прискорюючи процеси товарообміну та оборотності капіталу, при цьому знижуючи запаси матеріалів та готової продукції на складах, що дозволяє задовольнити потреби споживачів.

Задля збереження існуючих та формування нових конкурентних переваг логістичної компанії вкрай важливими є наявність та використання підприємством сучасних інформаційних технологій і платформ, а також моделей управління, що необхідні для оптимізації руху товарів та послуг, ресурсів та інших об'єктів. 3 появою нових платформ, систем та інформаційних технологій стає можливим розроблення різних математичних методик для спрощення логістичних завдань та їх практичної реалізації. Однак, зважаючи на особливості нормативного законодавства, що регулює питання облікового відображення нематеріальних активів можна, стверджувати, що не всі ті ресурси згадані вище, які потенційно забезпечують конкурентні переваги логістичної компанії на ринку, відображаються в системі обліку у складі нематеріальних активів, що ускладнює порядок управління ними. Як наслідок, виникає проблема щодо надання достовірної та релевантної інформації про такі активи логістичного підприємства зовнішнім і внутрішнім користувачам, що є однією з подальших перспектив наукових досліджень.

\section{Список використаної літератури:}

1. Безсмертна О.В. Інновації як ключовий фактор розвитку логістичних процесів у сучасній економіці / О.В. Безсмертна, С.С. Денисевич, Д.С. Зайцева // Young Scientist. - 2017. - № 12 (52). - С. $559-563$.

2. Григорак М.Ю. Аналіз бізнес-моделей та стратегій інноваційного розвитку постачальників логістичних послуг / М.Ю. Григорак // Технологический аудит и резервы производства. - 2016. - № 2/5 (28). - С. $29-38$.

3. Елфимова И.Ф. Управление инновационной деятельностью предприятия на основе логистического подхода / И.Ф. Елфимова, Р.С. Токарев // ЭКОНОМИНФО. - 2018. - Т. 15. - № 4. - С. $22-27$.

4. Кривещенко В.В. Як COVID-2019 може змінити майбутнє світової логістики? / В.В. Кривещенко, Д.Катрич // Сучасні технології комерційної діяльності і логістики : зб. матеріалів Міжнар. наук.-практ. інтернет-конф. (21-22 трав. 2020 р.). - Київ, 2020. - С. 180-182.

5. Позняк О.В. Економічні ресурси логістики як основа конкурентних переваг / О.В. Позняк // Збірник наукових праць ДЕТУТ. Серія : «Економіка і управління». - 2015. - № 31. - С. 252-260.

6. Похильченко О.А. Тренди логістики та supply chain management в проекції трансформаційних змін industry 4.0. / О.А. Похильченко // Інтелект XXI. - 2019. - № 3. - С. 149-154.

7. Bujak A. Innovations and changes in the logistics tasks implementations / A.Bujak, N.Gubskaya // Studia Ekonomiczne ; Uniwersytet Ekonomiczny w Katowicach. - 2012. - P. 45-58.

8. Ferreira $C$. The impact of intangibles on the performance of the major technological companies in the world / C.Ferreira // ISCTE. Business School. - 2018. - P. 1-61.

9. Graig T. Inaction by logistics service providers of e-commerce immediacy megatrend / T.Graig. - 2015 [Електронний ресурс]. - Режим доступу : https://www.linkedin.com/pulse/inaction-logistics-service-providersecommerce-immediacy-tom-craig.

10. Kawa A. Intangible assets as a source of competitive advantage for logistics service providers / A.Kawa, M.Anholcer // Research journal of the university of Gdańsk. - 2019. - Vol. 78. - P. 29-41.

11. Koláé J. Logistics activities in relation to tangible and intangible operations / J.Koláé. - 2016. - P. 29-34 [Електронний ресурс]. - Режим доступу : https://journals.vstecb.cz/wp-content/uploads/2016/04/LogisticsActivities-in-Relation-to-Tangible-and-Intangible-Operations-Ji\%C5\%99\%C3\%AD-KOL\%C3\%81\%C5\%981.pdf.

12. Ocak $M$. The impact of intangible assets and sub-components of intangible assets on sustainable growth and firm value: evidence from Turkish listed firms / M.Ocak, D.Fındık // Sustainability. - 2019. - № 11. - P. 2-23.

\section{References:}

1. Bezsmertna, O.V., Denysevych, Je.S. and Zajceva, D.Je. (2017), «Innovacii' jak kljuchovyj faktor rozvytku logistychnyh procesiv u suchasnij ekonomici», Young Scientist, No. 12 (52), pp. 559-563.

2. Grygorak, M. Ju. (2016), «Analiz biznes-modelej ta strategij innovacijnogo rozvytku postachal'nykiv logistychnyh poslug», Tekhnologicheskii audit i rezervy proizvodstva, No. 2/5 (28), pp. 29-38.

3. Elfimova, I.F. and Tokarev, R.S. (2018), «Upravlenie innovatsionnoi deyatel'nost'yu predpriyatiya na osnove logisticheskogo podkhoda», EKONOMINFO, Vol. 15, No. 4, pp. 22-27.

4. Kryveshhenko, V.V. and Katrych, D. (2020), «Jak COVID-2019 mozhe zminyty majbutnje svitovoi' logistyky?», Suchasni tehnologii' komercijnoi' dijal'nosti i logistyky, zb. materialiv Mizhnar. nauk.-prakt. internet-konf., Kyi'v, Ukraine, pp. 180-182,.

5. Poznjak, O.V. (2015), «Ekonomichni resursy logistyky jak osnova konkurentnyh perevag», Zbirnyk naukovyh prac' DETUT, Serija Ekonomika i upravlinnja, No. 31, pp. 252-260.

6. Pohyl'chenko, O.A. (2019), «Trendy logistyky ta supply chain management v proekcii' transformacijnyh zmin industry 4.0.», Intelekt XXI, No. 3, pp. 149-154. 
7. Bujak, A. and Gubskaya, N. (2012), «Innovations and changes in the logistics tasks implementations», Studia Ekonomiczne, Uniwersytet Ekonomiczny w Katowicach, pp. 45-58.

8. Ferreira, C. (2018), «The impact of intangibles on the performance of the major technological companies in the world», ISCTE. Business School, pp. 1-61.

9. Graig, T. (2015), Inaction by logistics service providers of e-commerce immediacy megatrend, [Online], available at: https://www.linkedin.com/pulse/inaction-logistics-service-providers-ecommerce-immediacy-tom-craig

10. Kawa, A. and Anholcer, M. (2019), «Intangible assets as a source of competitive advantage for logistics service providers», Research journal of the university of Gdańsk, Vol. 78, pp. 29-41.

11. Koláé, J. (2016), Logistics activities in relation to tangible and intangible operations, pp. 29-34, [Online], available at: https://journals.vstecb.cz/wp-content/uploads/2016/04/Logistics-Activities-in-Relation-to-Tangibleand-Intangible-Operations-Ji\%C5\%99\%C3\%AD-KOL\%C3\%81\%C5\%981.pdf,

12. Ocak, M. and Findık, D. (2019), «The impact of intangible assets and sub-components of intangible assets on sustainable growth and firm value: evidence from Turkish listed firms», Sustainability, No. 11, pp. 2-23.

Легенчук Сергій Федорович - доктор економічних наук, професор, завідувач кафедри інформаційних систем в управлінні та обліку Державного університету «Житомирська політехніка».

Наукові інтереси:

- розвиток теорії і методології бухгалтерського обліку;

- позитивна теорія бухгалтерського обліку;

- бухгалтерський облік нематеріальних активів.

Очередько Вікторія Романівна - магістрант кафедри інформаційних систем в управлінні та обліку Державного університету «Житомирська політехніка».

Наукові інтереси:

- бухгалтерський облік та оцінка нематеріальних активів.

Орлов Ігор Віталійович - доктор економічних наук, професор, професор кафедри обліку і аудиту Закарпатського угорського інституту імені Ференца Ракоці II.

Наукові інтереси:

- теорія і методологія обліку і контролю зобов'язань;

- облік нематеріальних активів.

Стойка Наталія Степанівна - кандидат економічних наук, доцент, доцент кафедри обліку і аудиту Закарпатського угорського інституту імені Ференца Ракоці II.

Наукові інтереси:

- теорія і методологія обліку в системі збалансованих показників;

- контролінг підприємств. 